\title{
Non-traumatic splenic rupture in a patient on oral anticoagulation
}

\author{
Marije M de Kubber ${ }^{1 *}$, Lucia JM Kroft ${ }^{2}$ and Bas de Groot ${ }^{1}$
}

\begin{abstract}
Background: Splenic injury is normally associated with trauma, but spontaneous splenic rupture has been described in various systemic diseases.

Case presentation: A 56-year-old male on oral anticoagulation presented to the emergency department with epigastric pain, nausea, and left upper quadrant tenderness. There was no history of trauma. Contrast-enhanced CT imaging revealed a large subcapsular haematoma of the spleen. Oral anticoagulation was antagonised with vitamin $\mathrm{K}$ and the patient was discharged in good condition after 3 days of clinical observation.
\end{abstract}

Conclusion: Non-traumatic splenic rupture is a rare complication of oral anticoagulation.

Keywords: Non-traumatic splenic rupture, Spleen, Oral anticoagulation, Epigastric pain

\section{Findings}

Spontaneous splenic rupture is a rare and life-threatening condition. It is associated with pre-existent splenic pathology and various disease entities. Few reports have described the association with oral anticoagulation. Treatment normally consists of discontinuation of oral anticoagulation and surgery for patients in shock $[1,2]$.

\section{Case presentation}

A 56-year-old Caucasian male with a past medical history of hypertension, acute coronary syndrome and atrial fibrillation presented to the emergency department (ED) with acute epigastric pain. His complaints had started 2 weeks earlier and had worsened 1 day prior to ED presentation. The pain was associated with nausea and increased on inspiration. Defecation and micturition were normal. In addition to fenprocoumon and sotalol, he was on antihypertensives, a statin and a proton-pump inhibitor. There was no history of trauma. Physical examination showed a pale, sweating and obese man in pain. His blood pressure was 113/73 $\mathrm{mmHg}$, with a heart rate of 72 beats/min, oxygen saturation of $95 \%$ on room air and a respiratory rate of 13 breaths/min. The abdomen was not distended, and

\footnotetext{
* Correspondence: m.m.de_kubber@lumc.nl

${ }^{1}$ Department of Emergency Medicine, Leiden University Medical Centre,

Albinusdreef 2, 2333 Leiden, ZA, the Netherlands

Full list of author information is available at the end of the article
}

there were normal bowel sounds. He had epigastric tenderness without muscular defence or hepatosplenomegaly. His initial haemoglobin was $8.5 \mathrm{mmol} / \mathrm{l}$. White blood cell count was $8.5 \times 10^{9} / 1$ with a c-reactive protein of $26 \mathrm{mg} / \mathrm{l}$. The international normalised ratio (INR) was 2.4. Abdominal ultrasound showed an inhomogeneous aspect of the spleen without free fluid. Contrast-enhanced computed tomography (CT) imaging of the abdomen revealed splenic haemorrhage with subcapsular hematoma (Figure 1).

An acute operation was deemed unnecessary because his vital signs remained stable. Oral anticoagulation was reversed with $10 \mathrm{mg}$ vitamin $\mathrm{K}$. The patient was admitted to the hospital for observation and was discharged in good condition after 3 days.

\section{Discussion}

Non-traumatic splenic rupture may occur as a complication of neoplastic, infectious, inflammatory and genetic disorders. Various drugs and treatment modalities have also been associated with non-traumatic splenic rupture. In the presented case no other cause except for oral anticoagulation was found.

Mortality is relatively low when an underlying aetiology is absent but can be as high as $12.2 \%$ when caused by an underlying disease [3]. Patients typically present with abdominal pain, referring pain to the left shoulder and sometimes shock [1].

\section{Springer}



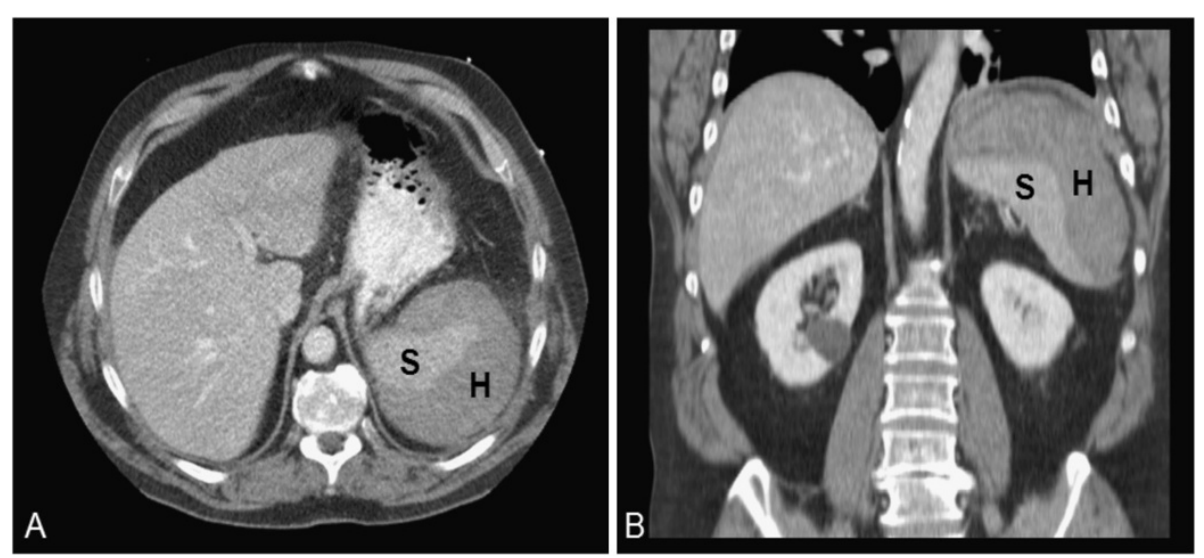

Figure 1 Contrast-enhanced computed tomography image with 5-mm slides in transverse (A) and coronal (B) orientation. Spleen (S) with large subcapsular hematoma $(\mathrm{H})$ with an estimated volume of $0.75 \mathrm{I}$.

Radiologic investigations play a major role in diagnosing spontaneous splenic injury. CT imaging has a sensitivity and specificity of at least 95\% [4].

Haemodynamically stable patients with non-traumatic splenic rupture are normally treated conservatively, while patients with active bleeding or shock usually require an operation, according to the guidelines of the Eastern Association of Surgery of Trauma (EAST) [2].

\section{Conclusion}

Non-traumatic splenic rupture is a rare complication of oral anticoagulation.

\section{Competing interests}

The authors declare that they have no competing interests.

\section{Authors' contributions}

MM carried out the literature research and wrote the manuscript. $\sqcup M$ provided the imaging picture. $\mathrm{LM}$ and $\mathrm{B}$ provided critical revision of the manuscript. All authors read and approved the final manuscript.

\section{Author details}

'Department of Emergency Medicine, Leiden University Medical Centre, Albinusdreef 2, 2333 Leiden, ZA, the Netherlands. 'Department of Radiology, Leiden University Medical Centre, Albinusdreef 2, 2333 Leiden, ZA, the Netherlands.

Received: 21 March 2013 Accepted: 9 April 2013

Published: 21 May 2013

\section{References}

1. Blankenship JC, Indeck M: Spontaneous splenic rupture complicating anticoagulant or thrombolytic therapy. Am J Med 1993, 94(4):433-437.

2. Stassen NA, Bhullar I, Cheng JD, Crandall ML, Friese RS, Guillamondegui OD, Jawa RS, Maung AA, Rohs TJ Jr, Sangosanya A, Schuster KM, Seamon MJ, Tchorz KM, Zarzuar BL, Kerwin AJ; Eastern Association for the Surgery of Trauma. Selective nonoperative management of blunt splenic injury: an Eastern Association for the Surgery of Trauma practice management guideline. I Trauma Acute Care Surg. 2012 Nov; 73(5 Suppl 4):S294-300
3. Renzulli P, Hostettler A, Schoepfer AM, Gloor B, Candinas D: Systematic review of atraumatic splenic rupture. Br J Surg 2009, 96(10):1114-1121.

4. Jeffrey RB, Laing FC, Federle MP, Goodman PC: Computed tomography of splenic trauma Radiology. Radiology 1981 141(3):729-732.

doi:10.1186/1865-1380-6-16

Cite this article as: de Kubber et al: Non-traumatic splenic rupture in a patient on oral anticoagulation. International Journal of Emergency Medicine 2013 6:16.

\section{Submit your manuscript to a SpringerOpen ${ }^{\circ}$ journal and benefit from:}

- Convenient online submission

- Rigorous peer review

- Immediate publication on acceptance

- Open access: articles freely available online

- High visibility within the field

- Retaining the copyright to your article

Submit your next manuscript at $>$ springeropen.com 